\title{
Strategi Ekspansi PT. Garuda Indonesia Tbk melalui Kolaborasi Internasional dengan SkyTeam Airline Alliance
}

\author{
Ni Made Citra Kusuma Dewi \\ Universitas Airlangga
}

\begin{abstract}
ABSTRAK
Pada 5 Maret 2014, Garuda Indonesia resmi bergabung dalam SkyTeam Airline Alliance dan menjadi maskapai Indonesia pertama yang terlibat dalam aliansi maskapai penerbangan global tersebut. Tulisan ini lantas ditujukan untuk mengeksplorasi upaya ekspansi Garuda Indonesia melalui keanggotaannya dalam SkyTeam tersebut. Penulis menggunakan aliansi strategis dalam bisnis internasional untuk memahami relasi antara Garuda Indonesia dan SkyTeam. Penulis juga akan menyajikan sejumlah data guna membandingkan operasi bisnis Garuda Indonesia sebelum dan setelah bergabung dalam SkyTeam untuk mengetahui keberhasilan dari aliansi ini. Berdasarkan data-data yang telah dikumpulkan, penulis menemukan bahwa keanggotaan Garuda Indonesia dalam SkyTeam berimplikasi positif pada jumlah penumpang internasional, pendapatan usaha total, dan kualitas jasa Garuda Indonesia. Maka dari itu, penulis berargumen bahwa aliansi SkyTeam tidak hanya berperan dalam meningkatkan kuantitas keuntungan, tetapi juga kualitas layanan maskapai Garuda Indonesia.
\end{abstract}

Kata-kata Kunci: Garuda Indonesia, SkyTeam, ekspansi, aliansi strategis, aliansi maskapai penerbangan global

On March 5th 2014, Garuda Indonesia officially joined SkyTeam Airline Alliance and became the first Indonesian airline that takes part in the global airline alliance. Based on that case, the author aims to explore the expansion strategy of PT. Garuda Indonesa Tbk. through its membership in SkyTeam. The author will utilize the strategic alliance theory of International Business in understanding the relation between Garuda Indonesia and SkyTeam. The author will also provide several datas to compare the business operation of PT. Garuda Indonesia before and after joining SkyTeam Airline Alliance in order to analyze the impact of this alliance. According to the collected data, the author found that the membership of Garuda Indonesia in SkyTeam has shown positive impacts to the airline's number of international traffic, total operating revenues, as well as its quality of service. Therefore, the author argues that SkyTeam Airline Alliance contributes not only to the increase of profit earned by Garuda Indonesia, but also the airline's quality of service.

Keywords: Garuda Indonesia, SkyTeam, expansion, strategic alliance, global airline alliances 


\section{Pendahuluan}

Memasuki era globalisasi, masyarakat di seluruh dunia dapat saling berinteraksi secara langsung maupun tidak langsung tanpa mempermasalahkan aspek jarak dan waktu. Runtuhnya penghalang dalam berinteraksi tidak hanya didukung oleh kemajuan teknologi komunikasi, melainkan juga perkembangan pada teknologi transportasi canggih, terutama pesawat udara. Dengan pesawat udara, setiap orang mampu berpindah dari satu negara ke negara lainnya dalam waktu singkat. Seiring perkembangan zaman, transportasi udara pun dikategorikan sebagai salah satu industri mayor dalam perekonomian dunia (Tugores-García 2012). Terhitung sejak 1980-an, tingkat lalu lintas udara dunia meningkat sebesar lima persen, seiring dengan kontribusinya dalam pertumbuhan ekonomi. Pasalnya, kemampuan pesawat udara untuk menghantarkan orang dan barang ke berbagai belahan dunia dalam hitungan menit atau jam telah memfasilitasi perkembangan sektor pariwisata dan perdagangan. Masih berkaitan dengan pertumbuhan ekonomi, perkembangan pesat sektor industri penerbangan juga berkontribusi dalam pembentukan lapangan kerja di dunia. Berdasarkan estimasi Air Transport Action Group atau ATAG, dampak ekonomi total dari industri penerbangan global mencapai 2,7 triliun dolar Amerika Serikat-setara dengan 3,5 persen dari Produksi Domestik Bruto dunia - pada tahun 2014 (IATA 2017).

Tidak terhenti pada aspek ekonomi, perkembangan industri pesawat udara juga membawa keuntungan dalam aspek politik dan sosial. Berkembangnya transportasi udara memberi kesempatan bagi pemimpin berbagai negara untuk saling berkunjung, berkumpul, dan berdiskusi secara langsung mengenai berbagai isu yang sedang dihadapi dunia (Tugores-García 2012). Sementara dalam aspek sosial, ketersediaan jasa transportasi udara memudahkan setiap orang di dunia untuk mengakses pendidikan yang lebih baik dan pengalaman kultural baru secara langsung (IATA 2017). Signifikansi peran transportasi udara dalam kehidupan manusia dan perekonomian global akhirnya memunculkan berbagai upaya untuk mengembangkan industri penerbangan dunia. Akan tetapi, upaya-upaya tersebut kerap dihadapkan pada kendala regulasi internasional dalam melindungi kedaulatan negara atas wilayah udara. Mengacu pada isi Konvensi Chicago 1944, aktivitas penerbangan dunia harus memerhatikan lima prinsip kebebasan di ruang udara. Kebebasan tersebut meliputi dua kebebasan dasar yang meliputi hak lintas damai dan hak untuk mendarat untuk keperluan teknis, serta tiga 
kebebasan komersial berupa hak untuk menurunkan dan menaikkan penumpang atau barang di semua negara pihak penumpang dan negara-negara yang pesawatnya memiliki kebangsaan atas negara tersebut (Mauna 2015). Lebih lanjut, Gerhard von Glahn (1981) juga menjelaskan bahwa setiap negara maupun pelaku industri penerbangan perlu memahami bahwa seluruh ruang udara di atas negara tanpa adanya batas ketinggian dianggap sebagai udara nasional, sehingga hak lintas udara umumnya hanya diberikan pada pesawatpesawat yang kebangsaaanya terdaftar sebagai negara-negara sahabat.

Dengan prasyarat bahwa suatu pesawat udara harus mendaftarkan diri pada suatu negara untuk memeroleh identitas kebangsaan, regulasi-regulasi tersebut mengindikasikan bahwa bahwa rute dan frekuensi penerbangan pesawat udara ditentukan oleh perjanjian bilateral antara negara kebangsaan pesawat dengan negara lainnya. Untuk mengatasi hambatan tersebut, maskapai komersial selaku operator utama transportasi udara senantiasa mengembangkan skema kolaboratif melalui pembentukan aliansi maskapai penerbangan (Tugores-García 2012). Hingga saat ini, terdapat tiga aliansi maskapai penerbangan yang mendominasi industri penerbangan dunia, yakni Oneworld, Star Alliance, dan SkyTeam. Pada 5 Maret 2014 silam, PT. Garuda Indonesia menjadi maskapai penerbangan Indonesia pertama yang secara resmi bergabung dalam salah satu aliansi penerbangan terbesar di dunia, yakni SkyTeam Airline Alliance. Bergabungnya PT. Garuda Indonesia dalam SkyTeam Airline Alliance lantas membuka kesempatan bagi maskapai Garuda Indonesia untuk terhubung dengan 1.064 destinasi di 178 negara (Garuda Indonesia 2014). Tulisan ini ditujukan untuk mengeksplorasi upaya-upaya ekspansi yang dilakukan oleh PT. Garuda Indonesia Tbk. melalui keanggotaannya dalam aliansi maskapai penerbangan global SkyTeam. Berkaitan dengan tujuan tersebut, penulis akan memaparkan teori mengenai aliansi strategis sebagai salah satu mode ekspansi dalam bisnis internasional. Penulis pun akan menyajikan sejumlah data untuk membandingkan operasi bisnis PT. Garuda Indonesia Tbk. sebelum dan sesudah bergabung dalam SkyTeam. Dengan luasnya jangkauan rute internasional dan tingginya frekuensi penerbangan dari SkyTeam, penulis berargumen bahwa keanggotaan PT. Garuda Indonesia Tbk. dalam aliansi maskapai penerbangan global tersebut memberikan berbagai keuntungan, khususnya dalam hal peningkatan pada kuantitas penerbangan internasonal dan kualitas jasa dari maskapai Garuda Indonesia. 


\section{Pembentukan Aliansi Strategis sebagai Mode Ekspansi Industri Penerbangan Dunia}

Pada dasarnya, operasi bisnis internasional dapat dilakukan oleh suatu perusahaan secara mandiri atau melalui kolaborasi dengan perusahaan lainnya. Namun, pilihan atas mode operasi tersebut dipengaruhi oleh faktor eksternal dan internal yang berada di lingkungan operasi perusahaan. Daniels et al. (2015) menjabarkan bahwa faktor internal merujuk pada faktor-faktor yang dapat dikontrol oleh perusahaan, di antaranya: (1) faktor produksi yang meliputi modal, bahan mentah, dan sumber daya alam; dan (2) aktivitas organisasi seperti pengaturan keuangan dan pemasaran. Selain itu, faktor internal perusahaan juga dapat berupa objektif seperti ekspansi penjualan, akuisisi sumber daya, dan upaya meminimalkan risiko. Sebaliknya, faktor eksternal perusahaan merupakan segala faktor dalam lingkungan operasi yang tidak dapat dikontrol oleh perusahaan. Secara garis besar, faktor eksternal dapat berupa faktor fisik dan sosial. Hal-hal yang dikategorikan sebagai faktor eksternal yaitu: (1) daya saing, baik dalam aspek strategi produk, sumber daya dan pengalaman, serta pasar; (2) distribusi; (3) faktor ekonomi, seperti Produk Domestik Bruto (PDB) dan upah pekerja; (4) faktor sosio-ekonomi, seperti karakteristik populasi; (5) finansial, seperti suku bunga, pajak, dan tingkat inflasi; (6) legalitas, seperti kebijakan pemerintah dan hukum yang berlaku; (7) sosial-budaya, seperti sikap dan kepercayaan; (8) tenaga kerja; serta (9) teknologi (Daniels et al. 2015).

Dalam kajian bisnis internasional, terdapat tiga jenis mode entri yang dapat diterapkan oleh perusahaan untuk memperluas operasi bisnisnya. Mode entri tersebut meliputi: (1) ekspor, impor, dan countertrade; (2) mode entri kontraktual; dan (3) mode entri investasi. Meski dapat diterapkan pada perusahaan yang menjual jasa, mode entri ekspor, impor dan countertrade biasanya digunakan oleh korporasi-korporasi yang produknya bersifat tangible. Namun, tidak dapat dipungkiri bahwa beberapa perusahaan memiliki produk yang bersifat intangible seperti merek dagang, kemampuan manajemen, ataupun resep makanan, sehingga produk tersebut tidak dapat diperdagangkan secara terbuka dalam pasar konvensional. Pada kasus yang sedemikian rupa, perusahaan akan cenderung menerapkan mode entri kontraktual. Esensi utama dalam mode entri kontraktual adalah perjanjian atau kontrak dalam jangka waktu tertentu. Mode entri kontraktual juga membutuhkan komitmen antara pihak-pihak yang bersangkutan guna memastikan 
bahwa masing-masing pihak tidak melakukan pelanggaran atas halhal yang telah disepakati. Dalam mode entri investasi, perusahaan membutuhkan tingkat komitmen yang lebih tinggi dari yang dibutuhkan dalam mode entri kontraktual. Pasalnya, mode entri investasi dilakukan melalui investasi langsung yang diikuti dengan keterlibatan perusahaan dalam operasi di tingkat lokal. Terdapat setidaknya tiga bentuk kegiatan yang tergolong dalam mode entri investasi, yaitu: (1) kepemilikan penuh atas anak perusahaan; (2) joint venture; dan (3) aliansi strategis (Wild dan Wild 2016). Dalam industri penerbangan, mode entri yang paling umum digunakan adalah aliansi strategis. Bentuk entri inilah yang kemudian diterapkan oleh maskapai Garuda Indonesia melalui keanggotaannya dalam SkyTeam Airline Alliance.

Terminologi aliansi strategis dapat dipahami sebagai hubungan yang dibentuk oleh dua atau lebih korporasi guna mencapai tujuan strategisnya masing-masing, tanpa membentuk perusahaan terpisah. Aliansi strategis bersifat variatif, mulai dari kerja sama pengembangan pasar hingga kepemilikian bersama atas operasi bisnis di tingkat global (Czinkota dan Ronkainen 2013). Perusahaan dapat membangun aliansi strategis dengan entitas pemasok, pembeli, atau bahkan pesaingnya (Wild dan Wild 2016). Pembangunan aliansi bersama pesaing telah menjadi pola umum dalam industri penerbangan. Oum et al. (2000) kemudian menjelaskan bahwa aliansi strategis dalam penerbangan dapat didefinisikan sebagai kemitraan jangka panjang antara dua atau lebih maskapai penerbangan yang berusaha untuk meningkatkan keuntungan kompetitifnya secara kolektif dengan para pesaing mereka. Pembangunan kemitraan strategis dalam industri penerbangan meliputi pembagian sumber daya langka seperti merek dan kemampuan akses pasar, peningkatan kualitas layanan, dan dengan demikian juga peningkatan profitabilitas masing-masing maskapai yang terlibat. Dari segi praktis, aliansi strategis dalam industri penerbangan juga membutuhkan komitmen manajemen yang baik untuk menghubungkan bagian-bagian substansial dari jaringan rute maskapai yang menjadi anggotanya. Terlepas dari rumitnya bentuk kerja sama tersebut, Burton dan Hanlon (1994) berargumen bahwa aliansi merupakan formulasi sentral dalam strategi bisnis penerbangan. Meski demikian, pembentukan aliansi strategis dalam operasi bisnis penerbangan sejatinya dipengaruhi oleh sejumlah faktor internal dan eksternal dalam lingkungan operasi bisnisnya (Daniels et al. 2015). 
Sebagai salah satu faktor internal, motivasi utama maskapai penerbangan untuk bergabung dalam aliansi strategis adalah adanya kesempatan untuk melakukan ekspansi jaringan penerbangan secara internasional dan bahkan global. Mode ekspansi tersebut cenderung dilakukan oleh maskapai-maskapai penerbangan yang telah menempati posisi dominan di pasar negara asalnya. Melalui aliansi strategis dengan maskapai penerbangan internasional, maskapai-maskapai domestik tersebut akan memeroleh akses penerbangan ke negara kebangsaan dari maskapai anggota aliansinya (Goel 2003). Faktor internal selanjutnya adalah keinginan suatu maskapai untuk memeroleh efisiensi teknis, menekan biaya produksi, dan meningkatkan kualitas pelayanan. Hal ini dikarenakan aliansi memberikan akses pada maskapai yang menjadi anggotanya untuk mengonsolidasikan fasilitas, seperti basis maintenance. Di samping dua faktor tersebut, motivasi internal lainnya adalah keinginan suatu maskapai penerbangan untuk membatasi kompetisi dalam pasar transportasi udara. Dengan membentuk aliansi strategis, suatu maskapai penerbangan akan menyepakati perjanjian untuk bekerja sama dan tidak saling merugikan antara anggotaanggota aliansi lainya. Keuntungan tersebut diperoleh karena aliansi strategis dapat membentuk monopoli virtual dalam pasar antara hub dan rekan-rekan aliansinya (Youssef 1992).

Di samping itu, terdapat pula faktor-faktor eksternal yang mendorong maskapai penerbangan untuk membentuk aliansi strategis dengan kompetitornya. Salah satu dari faktor-faktor tersebut adalah restriksi pemerintah dan perjanjian internasional terkait kedaulatan negara atas wilayah udara. Negara pada umumnya membatasi kepemilikan asing terhadap maskapai udara yang terdaftar sebagai maskapai negaranya (Goel 2003). Pembatasan tersebutberhubungan dengan fungsi tanggung jawab dan fungsi perlindungan negara terhadap pesawat udara yang menggunakan bendera nasionalnya sebagai identitas. Fungsi tanggung jawab berkaitan dengan hak legal negara kebangsaan suatu pesawat udara untuk memberikan dokumen-dokumen teknis yang dibutuhkan saat penerbangan. Di sisi lain, fungsi perlindungan memberikan kapabilitas bagi pesawat yang beroperasi untuk meminta bantuan pada perwakilan diplomatik negaranya apabila pesawat sewaktu-waktu mengalami kendala saat sedang beroperasi di luar negeri (Mauna 2015). Hambatan eksternal lainnya adalah keengganan negara untuk mengakui beberapa prinsip demi menjaga kedaulatan wilayah teritorialnya. Sikap tersebut tercermin dalam ketiadaan perjanjian internasional resmi untuk menyepakati beberapa prinsip kebebasan udara yang 
diusulkan oleh International Civil Aviation Organization atau ICAO.

Hingga saat ini, prinsip-prisip kebebasan udara ICAO yang belum diakui secara internasional meliputi: (1) kebebasan udara keenam, yakni hak untuk mengangkut dan menurunkan penumpang atau barang dari satu negara ke negara lain, dengan persetujuan negara tujuan dan dengan melewati negara asal dari maskapai penerbangan itu sendiri; (2) kebebasan udara ketujuh, yakni hak yang diberikan oleh satu negara ke negara lain untuk menaikkan dan menurunkan penumpang dari wilayah negara pemberi hak menuju kota di negara lainnya-atau sebaliknya-tanpa melewati negara asal; (3) kebebasan kedelapan atau yang dikenal sebagai consecutive cabotage, yakni hak untuk menaikkan dan menurunkan penumpang pada dua titik dalam satu wilayah teritorial negara oleh maskapai penerbangan yang bukan berasal dari negara tersebut; dan (4) kebebasan kesembilan atau stand alone cabotage, yakni hak untuk menaikkan dan menurunkan penumpang di seluruh titik dalam satu wilayah teritorial negara oleh maskapai penerbangan yang bukan berasal dari negara tersebut (ICAO 2018).

Sebagai konsekuensi dari belum adanya pengakuan internasional tersebut, jangkauan akses penerbangan maskapai komersial ditentukan oleh sejumlah kesepakatan bilateral yang dilakukan oleh negara terkait kebebasan dalam mengakses wilayah udara negara lainnya. Situasi eksternal tersebut lantas meningkatkan urgensi bagi pembentukan aliansi antara maskapai-maskapai yang ingin menjangkau penerbangan internasional atau global, mengingat aliansi strategis dapat menyediakan perjanjian codeshare yang luas. Adapun yang dimaksud sebagai perjanjian codeshare adalah perjanjian bisnis penerbangan yang memampukan penumpang untuk membeli satu kursi dari satu maskapai. Namun, demi kemudahan akses pada beberapa negara, penerbangan tersebut sesungguhnya dapat dioperasikan oleh maskapai penerbangan lain dalam aliansi dengan nomor dan kode penerbangan yang berbeda. Terdapat sejumlah ketentuan umum dalam perjanjian codeshare antara maskapai-maskapai penerbangan, yakni: (1) daftar rute yang berfungsi untuk menentukan rute-rute yang termasuk dalam perjanjian; (2) pemasaran dan pameran produk, yakni izin bagi masingmasing maskapai untuk memasarkan penerbangan di bawah kodenya sendiri; (3) produk in-flight dan pengawasan kualitas, yaitu kesepakatan yang memuat batas minimum operasional dan pelayanan darat maupun in-flight dari masing-masing maskapai 
yang bersangkutan; (4) penanganan penumpang dan prosedur bandara, yang berisi detail prosedur dalam menangani penumpang seperti check-in, transit, transfer penerbangan, dan pengambilan bagasi; dan (5) prosedur pengelolaan inventaris, yakni poin perjanjian yang mengatur perihal pendapatan dan pemetaan pemesanan kursi di pesawat (Gleave 2007).

\section{Operasi Global SkyTeam dan Kontribusinya dalam Upaya Pencapaian Objektif Garuda Indonesia}

Secara historis, pembentukan aliansi penerbangan SkyTeam berkaitan dengan perkembangan skema hub-and-spoke dan kebutuhan maskapai untuk membangun jaringan domestik maupun internasional. Ide-ide untuk membangun aliansi strategis dalam industri transportasi udara meningkat setelah Amerika Serikat mencetuskan Deregulation Act pada 1978. Saat itu, Amerika Serikat mulai merombak struktur jaringan penerbangannya dari skema point-topoint menjadi hub-and-spoke demi meningkatkan efisiensi. Skema point-to-point menggambarkan bahwa suatu maskapai penerbangan dapat terbang dari satu kota ke kota tujuan tanpa perlu singgah atau transit di kota lainnya. Sebaliknya, skema hub-and-spoke melibatkan alur penerbangan di mana suatu maskapai akan berhenti pada bandara di sebuah kota yang telah ditetapkan sebagai hub. Bandara $h u b$ biasanya terletak di kota-kota besar yang terhubung dengan beberapa titik kota atau spoke. Penerapan skema hub-and-spoke kemudian memungkinkan maskapai penerbangan untuk mengumpulkan penumpang dengan destinasi yang sama, namun berasal dari kota yang berbeda. Setelah penumpang tersebut dikumpulkan pada $h u b$, maka maskapai yang beraliansi dapat menggunakan satu pesawat udara untuk menerbangkan penumpang tersebut sehingga frekuensi penerbangan dan jumlah penumpang pesawat dapat dioptimalkan (Tugores-García 2012).

Di tengah upaya pengembangan bisnis transportasi udara ke ranah internasional, berbagai maskapai penerbangan mulai menyadari bahwa pengelolaan dan pengoperasian $h u b$ di luar negeri tidak mudah direalisasikan karena alasan-alasan politik. Hampir seluruh negara di dunia menerapkan regulasi yang membatasi praktik cabotage dan kepemilikan maskapai nasional oleh pihak asing. Akhirnya, maskapai-maskapai penerbangan dengan jaringan domestik yang kuat mulai membentuk aliansi untuk memaksimalkan jaringan hub-nya (Tugores-García 2012). Kondisi-kondisi inilah 
yang melatarbelakangi pembentukan SkyTeam yang kini dikategorikan sebagai aliansi maskapai penerbangan global. Pembentukan aliansi tersebut bermula dari penandatanganan kesepakatan strategis jangka panjang antara Delta Airlines dan Air France pada 22 Juni 1999. Kemudian pada 22 Juni 2000, Chief Executive Officer (CEO) Delta Air Lines, Aeroméxico, Air France, dan Korean Air bertemu di New York untuk meresmikan pembentukan SkyTeam Airline Alliance. Apabila dibandingkan dengan Star Alliance dan Oneworld, SkyTeam merupakan aliansi terakhir yang terbentuk, namun berhasil melampaui Oneworld dan menjadi aliansi maskapai penerbangan terbesar kedua di dunia (Truxal 2012). Pada bulan September di tahun yang sama, SkyTeam mengembangkan fokus aliansinya pada jasa kargo dan mengumumkan pembentukan SkyTeam Cargo. Pada tahun 2014, Garuda Indonesia resmi bergabung dalam SkyTeam sebagai anggota ke-20 (SkyTeam 2018).

Masuknya Garuda Indonesia turut berkontribusi dalam perluasan jaringan SkyTeam, sebab Garuda Indonesia membuka akses ke 30 destinasi baru pada aliansi tersebut. Bergabungnya Garuda Indonesia pada 5 Maret 2014 telah memperluas kehadiran SkyTeam di kawasan Asia Tenggara, meresmikan kehadiran aliansi maskapai tersebut di 18 negara yang tersebar di lima benua berbeda. Reputasi Garuda Indonesia sebagai maskapai dengan jaringan penerbangan yang luas di tingkat domestik maupun regional memberikan SkyTeam keuntungan berupa koneksi baru yang tersebar hingga wilayah Asia Pasifik. Dari 30 destinasi yang dibuka Garuda Indonesia untuk jaringan aliansi SkyTeam, beberapa di antaranya meliputi kota Surabaya di Jawa Timur, kota Medan di Sumatera Utara, dan Perth di Australia. Selain tawaran perluasan koneksi, CEO SkyTeam yakni Leo van Wijk (dalam SkyTeam 2010) menyatakan bahwa penerimaan Garuda Indonesia sebagai anggota juga didukung oleh restrukturisasi finansial dan operasional yang positif dari Garuda Indonesia sebelum resmi bergabung dalam SkyTeam. Peningkatan kualitas tersebut juga dibuktikan dengan penobatan Garuda Indonesia sebagai “World's Most Improved Airline” oleh Skytrax pada 2010 silam. Kemajuan tersebut lantas menonjolkan citra positif Indonesia yang sedang mengalami pembangunan ekonomi dengan signfikan (SkyTeam 2010).

Melalui SkyTeam Press Release (2010), Emisyah Satar selaku Presiden dan CEO dari PT. Garuda Indonesa Tbk. menyatakan bahwa bergabungnya Garuda Indonesia dengan SkyTeam merupakan strategi jangka panjang bagi Garuda Indonesia untuk 
meningkatkan pelayanan pada penumpang sekaligus berkooperasi dengan maskapai penerbangan anggota SkyTeam lainnya. Lebih lanjut, Emirsyah Satar menyebutkan bahwa keanggotaan Garuda Indonesia dalam SkyTeam juga tidak lepas dari target strategis Garuda Indonesia untuk senantiasa memperkuat profitabilitas dan meningkatkan daya saing di pasar internasional. Mengutip Direktur Pengelola SkyTeam, Marie-Joseph Malé (dalam SkyTeam 2010), salah satu pertimbangan utama Garuda Indonesia untuk bergabung dalam SkyTeam adalah intense maskapai tersebut untuk memperluas jaringan interkontinentalnya ke kota Frankfurt, Paris, London, dan Roma. Dengan demikian, Garuda Indonesia dapat meningkatkan daya tariknya pada penumpang yang bepergian untuk tujuan bisnis maupun liburan. Meskipun terdapat dua aliansi global lain yang memiliki reputasi positif, yakni Star Alliance dan Oneworld, terdapat beberapa alasan yang mendorong Garuda Indonesia untuk memilih SkyTeam sebagai aliansinya. Alasan-alasan tersebut adalah sebagai berikut: (1) Stars Alliance telah merekrut maskapai lain yang juga memiliki basis operasi di kawasan Asia Tenggara, yakni Thai Airways dan Singapore Airline. Jika Garuda Indonesia tetap bergabung dalam aliansi tersebut, maka akan ada sejumlah rute yang tumpang tindih; (2) meskipun Oneworld merupakan opsi yang memungkinkan, Garuda Indonesia tidak memiliki relasi yang dekat dengan anggota-anggota Oneworld Alliance; (3) sebelum resmi merekrut Garuda Indonesia, SkyTeam tidak memiliki aliansi dengan maskapai di kawasan Asia Tenggara. Seperti yang telah dipaparkan sebelumnya, bergabungnya Garuda Indonesia memberi keuntungan bagi SkyTeam untuk memperluas jaringan penerbangannya di Asia Tenggara dan sebaliknya, Garuda Indonesia memeroleh keuntungan berupa pembukaan akses ke beberapa destinasi internasional. Selain itu, Garuda Indonesia memiliki relasi yang baik dengan sejumlah anggota SkyTeam, yakni Korean Airlines dan KLM. Relasi tersebut terbentuk karena Garuda Indonesia telah menentukan berbagai rute penerbangan dengan KLM dan Korean Airline melalui perjanjian codeshare dan pembagian terminal (Fahriza 2016). 
Tabel 1. Maskapai Anggota SkyTeam

\begin{tabular}{|c|c|c|c|c|}
\hline Maskapai & Bergabung & Bendera & Destinasi & \begin{tabular}{|c|} 
Jumlah \\
Penumpang \\
/ Tahun
\end{tabular} \\
\hline AEROFLOT $\theta$ & 2006 & Rusia & $\begin{array}{c}146 / 52 \\
\text { negara }\end{array}$ & 32,8 juta \\
\hline A DELTA & 2000 & $\begin{array}{c}\text { Amerika } \\
\text { Serikat }\end{array}$ & $\begin{array}{c}324 / 57 \\
\text { negara }\end{array}$ & 180 juta \\
\hline AEROMEXICO. & 2000 & Meksiko & $\begin{array}{l}92 / 24 \\
\text { negara }\end{array}$ & 20,7 juta \\
\hline KOREAN AIR & 2000 & $\begin{array}{l}\text { Korea } \\
\text { Selatan }\end{array}$ & $\begin{array}{c}123 / 43 \\
\text { negara }\end{array}$ & 26,7 juta \\
\hline AerolíneasArgentinas & 2012 & Argentina & $\begin{array}{l}58 / 13 \\
\text { negara }\end{array}$ & 13,1 juta \\
\hline CHINA AIRLINES & 2011 & Taiwan & $\begin{array}{c}156 / 29 \\
\text { negara }\end{array}$ & 15,1 juta \\
\hline CHINA EASTERN & 2011 & Tiongkok & $\begin{array}{c}257 / 35 \\
\text { negara }\end{array}$ & 103,1 juta \\
\hline R Kenya Airways & 2007 & Kenya & $\begin{array}{l}52 / 40 \\
\text { negara }\end{array}$ & 4,5 juta \\
\hline (8) типом & 2010 & Rumania & $\begin{array}{l}40 / 23 \\
\text { negara }\end{array}$ & 2,4 juta \\
\hline Garuda Indonesia & 2014 & Indonesia & $\begin{array}{l}90 / 14 \\
\text { negara }\end{array}$ & 24 juta \\
\hline HMIA & 2012 & Lebanon & $\begin{array}{l}32 / 23 \\
\text { negara }\end{array}$ & 3 juta \\
\hline $\begin{array}{l}\text { TSA CZECH } \\
\text { AIRUINES }\end{array}$ & 2001 & Cekoslowakia & $\begin{array}{l}49 / 26 \\
\text { negara }\end{array}$ & 2,9 juta \\
\hline Q AirEuropa & 2007 & Spanyol & $\begin{array}{l}53 / 23 \\
\text { negara }\end{array}$ & 10,6 juta \\
\hline XIAMENAIR & 2012 & Tiongkok & $\begin{array}{l}94 / 16 \\
\text { negara }\end{array}$ & 27,2 juta \\
\hline devietnamAirlines & 2010 & Vietnam & $\begin{array}{l}49 / 17 \\
\text { negara }\end{array}$ & 26,5 juta \\
\hline KLัM & 2004 & Belanda & $\begin{array}{c}164 / 73 \\
\text { negara }\end{array}$ & 32,7 juta \\
\hline CHINA SOUTHERN & 2011 & Tiongkok & $\begin{array}{c}245 / 38 \\
\text { negara }\end{array}$ & 126 juta \\
\hline AIRFRANCE $\boldsymbol{z}$ & 2000 & Prancis & $\begin{array}{c}195 / 93 \\
\text { negara }\end{array}$ & 97,8 juta \\
\hline Mlitalia & 2009 & Italia & $\begin{array}{l}95 / 44 \\
\text { negara }\end{array}$ & 21,8 juta \\
\hline (7) SAUDIA & 2012 & Arab Saudi & $\begin{array}{l}90 / 37 \\
\text { negara }\end{array}$ & 31,2 juta \\
\hline
\end{tabular}

Sumber: Sumber: SkyTeam \& Member Factsheet 2018 
Berdasarkan data tabel 1, dapat dilihat bahwa SkyTeam memiliki jaringan penerbangan yang luas ke 1.064 kota di 178 negara. Dengan demikian, dengan bergabung dalam SkyTeam, Garuda Indonesia dapat terhubung de gan 1.064 kota destinasi di seluruh dunia. Operasi global SkyTeam juga mampu mengakomodasi objektif bisnis Garuda Indonesia yang berusaha memperluas jaringan penerbangannya ke beberapa kota, yakni Frakfurt, Paris, London, dan Roma. Akses tersebut diperoleh melalui perjanjian codeshare Garuda Indonesia dengan maskapai-maskapai SkyTeam yang menjadikan kota-kota tersebut sebagai destinasi penerbangannya, yakni Aeroflot, Air Europa, Air France, dan KLM (CAPA 2016).

Masih berkaitan dengan jaringan penerbangan SkyTeam yang luas, Garuda Indonesia juga memeroleh keuntungan dari segi penguatan brand. Sebagai anggota aliansi maskapai penerbangan terbesar di dunia, penguatan brand tersebut diperoleh melalui promosi atau pengenalan Garuda Indonesia di pasar-pasar baru, khususnya negara-negara kebangsaan dari maskapai-maskapai anggota SkyTeam (SkyTeam 2018). Lebih lanjut, dari segi operasi bisnisnya, SkyTeam Airline Alliance menerapkan sistem hub-and-spoke dengan 48 kota hub yang tersebar di lima benua (SkyTeam 2018). Melalui mekanisme hub-and-spoke tersebut, Garuda Indonesia pun memeroleh keuntungan berupa efisiensi waktu penerbangan dan penghematan biaya. Efisiensi waktu dan penghematan biaya dicapai melalui penerapan sistem co-location di bandara-bandara hub SkyTeam. Co-location merujuk pada penggunaan bersama gedung terminal bandara oleh tiga atau lebih anggota SkyTeam. Dengan sistem co-location tersebut, Garuda Indonesia dapat menekan waktu transit, mengoptimalkan fasilitas bandara, serta mengurangi biaya peralatan dan staf darat, mengingat peralatan dan staf darat juga akan digunakan bersama oleh beberapa maskapai penerbangan yang berada dalam terminal (Wu 2010). Saat ini, SkyTeam memiliki 6 co-location di Barcelona, Beijing, Budapest, Istanbul, London-Heathrow, dan Tokyo-Narita (SkyTeam 2018).

\section{Performa Garuda Indonesia setelah Menjadi Anggota SkyTeam}

Sejak pengadopsian Deregulation Act oleh Amerika Serikat pada 1978, perjanjian codeshare menjadi strategi unggulan maskapaimaskapai penerbangan komersial untuk memperluas pasarnya hingga tingkat internasional. Perjanjian codeshare juga menjadi 
program utama yang ditawarkan oleh berbagai aliansi penerbangan global, tak terkecuali SkyTeam Airline Alliance. Akan tetapi, perlu dipahami bahwa pemberlakuan perjanjian codeshare tidak bersifat otomatis bagi anggota aliansi penerbangan. Artinya, masing-masing maskapai penerbangan masih perlu melakukan negosiasi bilateral antaranggota guna mengatur perjanjian codeshare-nya. Hingga akhir 2017, Garuda Indonesia telah menjalin kerja sama codeshare dengan 14 anggota SkyTeam Airline Alliance. Secara keseluruhan, Garuda Indonesia kini memiliki 27 perjanjian codeshare dengan maskapai-maskapai penerbangan internasional yang tersebar di kawasan Asia Timur, Asia Tenggara, Timur Tengah, Eropa, bahkan Amerika Serikat (Garuda Indonesia 2017). Seiring berjalannya waktu, jumlah perjanjian codeshare Garuda Indonesia pun bertambah, seperti ditunjukkan dalam tabel 2.

\section{Tabel 2. Perkembangan Jumlah Perjanjian Codeshare Garuda Indonesia Tahun 2013-2017 (diolah).}

\begin{tabular}{|c|c|ll|}
\hline Tahun & $\begin{array}{c}\text { Jumlah } \\
\text { Codeshare }\end{array}$ & \multicolumn{1}{c|}{ Rekan Codeshare } \\
\hline 2013 & 14 & $\bullet$ & $\begin{array}{l}\mathbf{5} \text { anggota SkyTeam } \\
9 \text { anggota non SkyTeam }\end{array}$ \\
\hline 2014 & 21 & $\bullet$ & $\begin{array}{l}\mathbf{1 0} \text { anggota SkyTeam } \\
11 \text { anggota non-SkyTeam }\end{array}$ \\
\hline 2015 & 24 & $\bullet$ & $\mathbf{1 1}$ anggota SkyTeam \\
\hline 2016 & 26 & $\bullet$ & $\mathbf{1 3}$ anggota non-SkyTeam \\
\hline 2017 & 27 & $\bullet$ & $\mathbf{1 4}$ anggota SkyTeam \\
\hline
\end{tabular}

Sumber: Laporan Tahunan Garuda Indonesia 2017

Berdasarkan tabel 2, dapat dilihat bahwa jumlah perjanjian codeshare meningkat secara signifikan sejak 2014. Peningkatan tersebut bertepatan dengan masuknya Garuda Indonesia dalam aliansi global SkyTeam, tepatnya pada bulan Maret 2014. Hal ini juga ditunjukkan dengan peningkatan pada jumlah aliansi SkyTeam yang menjadi rekan codeshare Garuda Indonesia, yakni dari lima maskapai di tahun 2013 menjadi 10 maskapai di tahun 2014. Hingga penghujung 2017, lebih dari 50 persen rekan codeshare Garuda Indonesia meru- 
pakan anggota aliansi SkyTeam, di antaranya Aeroflot, Aeromexico, Air France, China Airlines, China Eastern Airlines, China Southern Airlines, Czech Airlines, Delta airlines, Korean Air, Kenya Airways, KLM, Vietnam Airlines, Xiamen Airlines, dan Aerolineas Argentinas (Garuda Indonesia 2017). Eskalasi jumlah perjanjian codeshare tersebut lantas berdampak pada jumlah penumpang rute internasional Garuda Indonesia, sebagaimana ditunjukkan dalam grafik 1.

\section{Grafik 1. Jumlah Penumpang Rute Internasional Garuda Indonesia Periode 2013-2017 (diolah).}

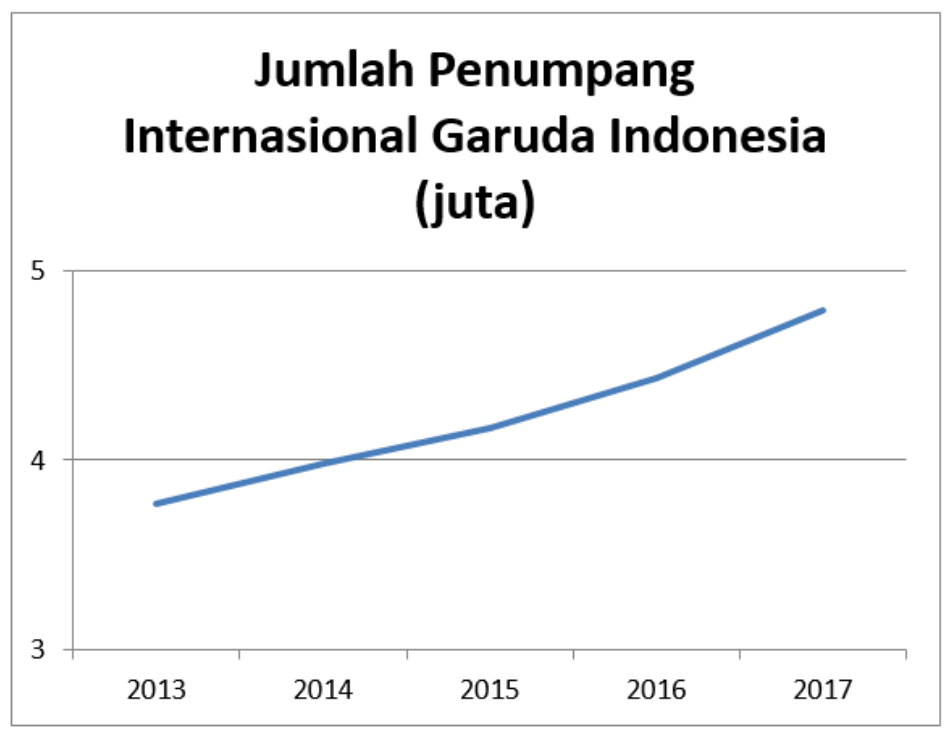

Sumber: Laporan Tahunan Garuda Indonesia 2017

Mengacu pada grafik tersebut, dapat dilihat bahwa angka penumpang internasional Garuda Indonesia meningkat secara bertahap. Diawali dengan angka 3,77 juta pada 2013, Garuda Indonesia telah berhasil menerbangkan 4,79 juta penumpang internasional sepanjang tahun 2017. Eskalasi penerbangan penumpang internasional tersebut didukung oleh perbaikan konektivitas penerbangan di pasar domestik maupun internasional. Peningkatan tersebut juga berkaitan dengan bertambahnya jumlah connecting flight hasil kerja sama codeshare Garuda Indonesia, yakni dari 4.531 di tahun 2016 menjadi 4.903 di tahun 2017. Setelah bergabung dengan SkyTeam, Garuda Indonesia tidak hanya menunjukan perkembangan dari segi kuantitas penerbangan, tetapi juga kualitas pelayanan. Pasalnya, SkyTeam menetapkan sejumlah standar ketat yang harus dipenuhi setiap maskapai anggota, khususnya dalam keselamatan penerbangan, 
teknologi, dan layanan pelanggan. Upaya Garuda Indonesia untuk menjaga kualitas pelayanannya dapat dilihat dalam keberhasilan Garuda Indonesia dalam mempertahankan penghargaan "The World's Best Cabin Crew" selama empat kali berturut-turut -yakni sejak tahun 2014 hingga 2017-dan penobatannya menjadi “The World's Most Loved Airlines" pada 2016. Dengan menjadi anggota SkyTeam, Garuda Indonesia juga memberi kesempatan bagi pengguna jasanya untuk menggunakan lounge terbaik yang disediakan SkyTeam di 672 bandara internasional (Garuda Indonesia 2017). Terlepas dari penurunan pendapatan yang terjadi sejak 2014 hingga 2015 akibat melambatnya pertumbuhan ekonomi, penurunan harga minyak, serta meningkatnya gejolak di pasar keuangan global, laporan tahunan Garuda Indonesia (2015) menunjukan bahwa SkyTeam berkontribusi dalam meningkatkan pendapatan usaha Garuda Indonesia. Kontribusi tersebut berakar pada peran aliansi SkyTeam dalam menyokong lalu lintas penumpang internasional, mendorong perbaikan kualitas layanan, serta menekan biaya operasional Garuda Indonesia melalui perjanjian codeshare dan sistem co-location di bandarahubinternasional. Perubahan pendapatan tersebut ditunjukkan dalam grafik 2, dengan rincian sebagai berikut: (1) 3.75 juta dolar AS pada 2013; (2) 3.93 juta dolar AS pada 2014; (3) 3.81 juta dolar AS pada 2015; (4) 3.86 juta dolar AS pada 2016; dan (5) 4.17 juta dolar AS pada 2017.

\section{Grafik 2. Jumlah Pendapatan Usaha Garuda Indonesia (dalam US\$) Periode 2013-2017 (diolah).}

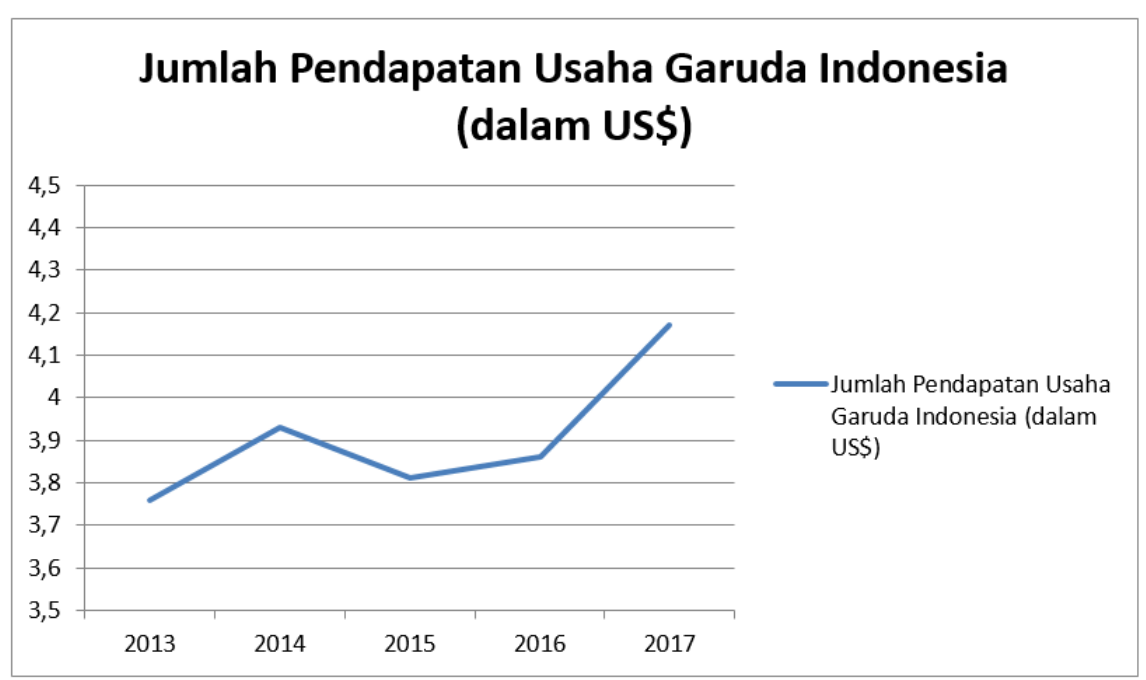

Sumber: Laporan Tahunan Garuda Indonesia 2017 


\section{Kesimpulan}

Bergabungnya Garuda Indonesia dalam aliansi strategis penerbangan global SkyTeam merupakan strategi ekspansi PT. Garuda Indonesia Tbk. ke pasar global. Keputusan Garuda Indonesia untuk terlibat dalam aliansi penerbangan global SkyTeam didasari oleh faktor internal dan faktor eksternal di lingkungan operasi bisnis penerbangan. Penulis menemukan setidaknya empat faktor internal yang melatarbelakangi tindakan Garuda Indonesia: (1) ambisi ekspansi ke pasar global; (2) keinginan untuk memeroleh efisiensi teknis; (3) keinginan untuk menekan biaya produksi; dan (4) kepentingan untuk meningkatkan kualitas pelayanan. Sementara faktor eksternal utama yang memengaruhi Garuda Indonesia adalah berbagai restriksi hukum udara internasional yang membatasi operasi penerbangan di beberapa wilayah demi menghormati kedaulatan teritorial negara. Dengan menjadi anggota aliansi SkyTeam, penulis juga melihat bahwa Garuda Indonesia memeroleh sejumlah keuntungan. Pertama, aliansi global SkyTeam memberikan Garuda Indonesia akses penerbangan ke 1.064 kota di 178 negara. Jumlah jaringan penerbangan tersebut akan senantiasa bertambah apabila SkyTeam merekrut anggota aliansi baru di masa depan. Kedua, operasi global SkyTeam telah mengakomodasi objektif Garuda Indonesia untuk membuka destinasi penerbangan ke kotakota krusial seperti Paris, London, Frankurt melalui perjanian codeshare. Tidak hanya pada negara-negara tersebut, perjanjian codeshare Garuda Indonesia dengan 14 maskapai internasional dalam SkyTeam juga memperluas jaringan internasional Garuda Indonesia ke sejumlah negara di berbagai benua. Ketiga, Garuda Indonesia berkesempatan untuk memperkuat brand-nya melalui promosi di pasar internasional, tepatnya negara anggota aliansi SkyTeam. Keempat, SkyTeam mengakomodasi kepentingan Garuda Indonesia untuk menekan biaya operasional melalui skema penerbangan internasional hub-and-spoke dan sistem co-location di gedung-gedung terminal bandara hub. Terakhir, keterlibatan dalam aliansi SkyTeam juga mendorong Garuda Indonesia untuk mempertahankan bahkan meningkatkan kualitas pelayanannya, terutama dalam aspek keselamatan, teknologi, dan kepedulian terhadap penumpang.

Segala implikasi positif tersebut akhirnya memengaruhi reputasi dan pendapatan usaha Garuda Indonesia. Hal ini dapat dilihat dari peningkatan jumlah penumpang internasional serta pendapatan usaha Garuda Indonesia dari tahun ke tahun. Namun, menyadur tulisan Bo Lin (2013), penulis juga beropini bahwa terdapat beberapa 
potensi risiko yang perlu diperhatikan Garuda Indonesia terkait keanggotaannya dalam SkyTeam. Pertama, kampanye branding yang agresif dan berkelanjutan dari aliansi dapat mengancam branding dari maskapai Garuda Indonesia sendiri. Kedua, ketidaksesuaian ekspektasi dan kesalahan koordinasi dapat memicu konflik antaranggota aliansi, mengingat masing-masing maskapai anggota memiliki kepentingan tersendiri yang ingin diperoleh melalui aliansi tersebut.

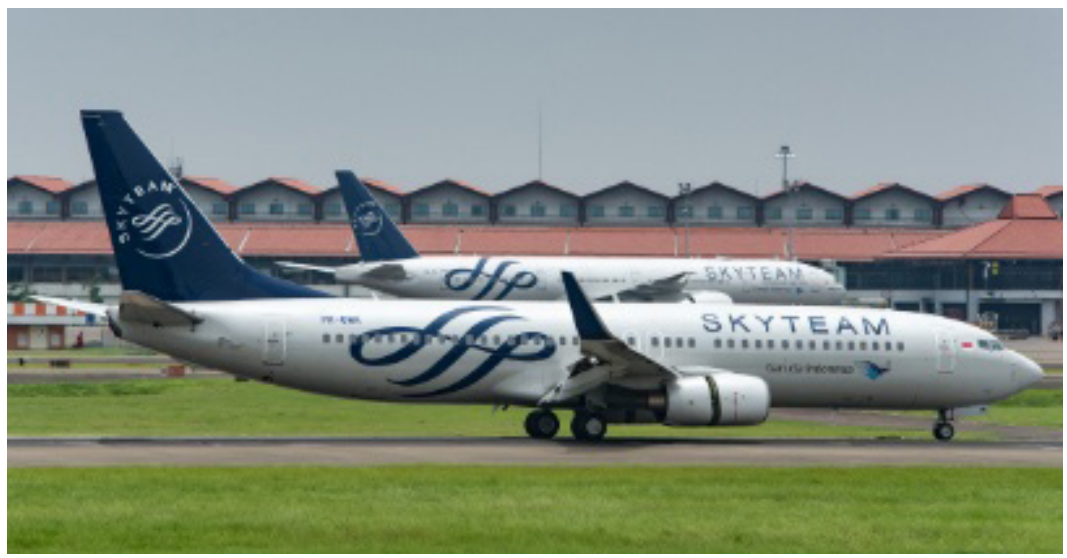

Sumber: www.garuda-indonesia.com 


\section{Daftar Pustaka}

\section{Artikel Daring}

CAPA, 2016. Garuda Indonesia Group [online]. Tersedia dalam https://centreforaviation.com/data/profiles/airlinegroups/garuda-indonesia-group [diakses 9 Desember 2018].

Goel, Abhishek, 2003. Strategic Alliances in the Global Airline Industry [online]. Tersedia dalam https://core.ac.uk/ download/pdf/6814210.pdf?repositoryId=153 [diakses 9 Desember 2018].

International Air Transport Association (IATA), 2017. "Aviation Benefits 2017" [online]. Tersedia dalam https://www.iata.org/policy/Documents/aviationbenefits-\%20web.pdf [diakses pada 7 Desember 2018].

International Civil Aviation Organization (ICAO), 2010. Freedoms of the Air [online]. Tersedia dalam https://www.icao.int/ Pages/freedomsAir.aspx [diakses 9 Desember 2018].

SkyTeam, 2010. Garuda Indonesia Joins SkyTeam: Alliance Expands its Reach in Southeast Asia and Australia [online]. Tersedia dalam https://www.skyteam.com/ en/about/press-releases/press-releases-2010/garudaindonesia-joins-skyteam/ diakses pada 7 Desember 2018].

SkyTeam, 2018. A History of Excellence: 2014 [online]. Tersedia dalam https://www.skyteam.com/en/about/history/2014/ [diakses 9 Desember 2018].

SkyTeam, 2018. SkyTeam Airline Member Benefits [online]. Tersedia dalam https://static.skyteam.com//contentapi/ globalassets/about-us/pdf/st-14-ff_member-benefits_ may.pdf?_ga = 2.215163283.580330170.15441751882089521242.1543672152 [diakses 9 Desember 2018].

\section{Artikel Jurnal}

Burton, John dan Pat Hanlon, 1994. "Airline Alliances: Cooperating to Compete?”, Journal of Air Transport Management, 1(4): 209-227. 
Fahriza, Basri, 2016. "Should Garuda Indonesia Join Three Major Airline Alliances: Star Alliance, Oneworld and SkyTeam", Jurnal Manajemen Bisnis Transportasi dan Logistik, 3(1), 123-139.

\section{Buku}

Czinkota Michael R. dan Ilkka A. Ronkainen, 2013. The Role of Culture. International Marketing. Boston: Cengage Learning.

Daniels, John. D., et al., 2015. International Business: Environment and Operation. New Jersey: Pearson Prentice Hall.

Glahn, Gerhard von, 1981. Law Among Nations. New York: Mac Millan Publishing Inc.

Mauna, Boer, 2015. Hukum Internasional: Pengertian, Peranan dan Fungsi dalam Era Dinamika Global. Bandung: PT Alumni.

Oum, T., et al., 2000. Globalisation and Strategic Alliances: The Case of Airline Industry. Oxford: Pergamon Press.

Truxal, S., 2012. Competition and Regulation in the Airline Industry: Puppets in Chaos. Abingdon: Routledge.

Wild, John dan Kenneth Wild, 2016. International Business: the Challenges of Globalization. London: Pearson.

Wu, C.L., 2010. Airline Operations and Delay Managements. London: Ashgate Publishing.

\section{Laporan Tahunan}

Garuda Indonesia, 2014. Laporan Tahunan 2014 [online]. Tersedia dalam https://www.garuda-indonesia.com/files/pdf/ investor-relations/report/2014.pdf [diakses 9 Desember 2018].

Garuda Indonesia, 2015. Laporan Tahunan 2015 [online]. Tersedia dalam https://www.garuda-indonesia.com/files/pdf/ 
investor-relations/report/2015.pdf [diakses 9 Desember 2018].

Garuda Indonesia, 2017. Laporan Tahunan 2017 [online]. Tersedia dalam https://www.garudaindonesia.com/files/pdf/investor-relations/report/2017v2.pdf [diakses 9 Desember 2018].

\section{Tesis dan Disertasi}

Gleave, Steer Davies, 2007. Competition Impact of Airline Codeshare Agreement [online]. Tersedia dalam http:// ec.europa.eu/competition/sectors/transport/reports/airlinecodeshare.pdf [diakses 9 Desember 2018].

Lin, Bo, 2013. The Effects of Joining Strategic Alliances Group on Airline Efficency, Productivity, and Profitability. Thesis of Doctorate of Philosophy in Aviation. Palmerston North, New Zealand: Massey University.

Tugores-García, Antonio, 2012. Analysis of Global Airline Alliances as a Strategy for International Network Development. Tesis Magister. Massachusetts: Massacushetts Institute of Technology.

Youssef, W., 1992. Causes and Effects of International Equity Alliances. Ph.D. dissertation Series UCB-ITS-DS-92-1. Berkley, CA: Institute of Transportation Studies, University of California. 